DOI: $10.1515 / \mathrm{rpp}-2016-0014$

Doctor of Pedagogical Sciences, Full Professor, NATALIYA MUKAN Lviv Polytechnic National University, Ukraine Address: 12 Stepan Bandera St., Lviv, 79013, Ukraine E-mail:nmukan@polynet.lviv.ua Senior Instructor, SVITLANA KRAVETS Lviv Polytechnic National University, Ukraine Address: 12 Stepan Bandera St., Lviv, 79013, Ukraine E-mail: s.f.kravets@gmail.com

Instructor, NATALIYA KHAMULYAK School of Intellectual Development "Yes, I Can", Ukraine Address: 63a Chornovola St., Lviv, 79059, Ukraine E-mail: eilatan@ukr.net

\title{
THE ANALYSIS OF CONTENT AND OPERATIONAL COMPONENTS OF PUBLIC SCHOOL TEACHERS' CONTINUING PROFESSIONAL DEVELOPMENT IN GREAT BRITAIN, CANADA AND THE USA
}

\begin{abstract}
In the article the content and operational components of continuing professional development of public school teachers in Great Britain, Canada, the USA have been characterized. The main objectives are defined as the theoretical analysis of scientificpedagogical literature, which highlights different aspects of the problem under research; identification of the common features of the content, models, forms and methods of continuing professional development of public school teachers. The legislative and normative framework of teachers' CPD in Great Britain, Canada and the USA, which determines the CPD content, has been highlighted; teachers' knowledge, skills, professional values and attitudes have been characterised; the key models, forms and methods of teachers' CPD have been defined. The teachers' CPD has been studied by foreign and Ukrainian scientists: models, forms and methods of teachers' CPD (L. Chance, A. Hollingsworth, D. Ross, E. Villegas-Reimers), non-formal teachers' CPD (J. Scheerens), continuing professional education (Ya. Belmaz, T. Desyatov), postgraduate education (A. Kuzminskyy, V. Russol), professional education (R. Hurevych, N. Nychkalo), teacher training (T. Koshmanova, Ye. Yevtukh), teachers' professional development ( $N$. Klokar, V. Oliynyk). The research methodology comprises theoretical (logical, induction and deduction, comparison and compatibility, structural and systematic, analysis and synthesis) and applied (observations, questioning and interviewing) methods. The research results have been presented.

Key words: public school teachers, continuing professional development, the content of CPD, models, forms and methods of CPD, legislative and normative framework, Great Britain, Canada, the USA.

\section{INTRODUCTION}

At the beginning of the $21^{\text {st }}$ century the special role is given to education. The main challenge of public school is determined as formation of students' readiness to solve complicated problems of everyday life. Special attention is paid to teachers' professional competence. Their activity is one of the most important factors of students' academic
\end{abstract}


success increasing. The necessity of continuing professional development is highlighted in order to ensure educational service of high quality and improve public school functioning.

The content of school education in Ukraine is being renovated, didactic systems, methods, pedagogical technologies are being updated, the possibilities of innovative forms application in educational process are being researched, the evaluative criteria of the work of educational institutions are being elaborated. This causes the necessity of teachers' continuing professional development, its modernization while taking into account modern changes of social development, innovation of personal and social demands, the development of methodical recommendations of its arrangement.

The research of productive ideas and experience of developed countries in the sphere of teachers' professional development is the essential source for determining the strategic ways of the development of continuing pedagogical education system in Ukraine. Great Britain, Canada and the USA are the countries that play the leading role in international educational area. These countries have significant pedagogical advances and developed systems of continuing pedagogical education, in the context of which public school teachers' professional development is performed.

The analysis of scientific works and the revealed contradictions in the national pedagogical environment justify the expediency and necessity of conducting this research.

\section{THE AIM OF THE STUDY}

The analysis of content and operational components of public school teachers' continuing professional development in Great Britain, Canada and the USA is the research aim. The authors have defined the following objectives: 1) to conduct the analysis of scientificpedagogical literature, which highlights different aspects of the problem under research and 2) to identify the common features of the content, models, forms and methods of continuing professional development of public school teachers in the countries under research.

\section{THEORETICAL FRAMEWORK AND RESEARCH METHODS}

Comparative-pedagogical research of the content and operational components of teachers' professional development in Great Britain, Canada and the USA is performed using the following concepts: analytical (analysis of the legislative and normative base of teachers' CPD in Great Britain, Canada and the USA), critical (analysis of knowledge, skills, values and attitudes of public school teachers in the discourse of their professional development) and unification mechanism of the information obtained as the result of studying the normative-legislative base and scientific-pedagogical literature.

The scientists research different aspects of public school teachers' CPD: political, social, cultural and economic features (L. Darling-Hammond, M. Tight); the development of CPD programs (C. Pratt); CPD content (N. Dana Fichtman, M. Rees, A. Ross, S. Zepeda); CPD models, forms and methods (P. Grimmet, K. Duinlan, G. Troia, P. Wong); teachers' activity during different periods of CPD (A. Charles, R. Ingersoll, S. Farrell) etc. Ukrainian researches study the specificity of teacher training: continuing professional education (Ya. Belmaz, T. Desyatov), postgraduate education (A. Kuzminskyy, V. Russol), professional education (S. Honcharenko, R. Hurevych, N. Nychkalo), teacher training (T. Koshmanova, O. Semenog, Ye. Yevtukh), teachers' professional development (V. Bykov, N. Klokar, V. Oliynyk).

The complex of theoretical methods has been used as the basis of the research: comparative method that allowed to study educational documents, normative-legislative regulations, laws on education, CPD Standards and scientific-pedagogical literature; induction and deduction used for gathering theoretical and factual material, its generalization as well 
as realization and interpretation of separate phenomena of pedagogical reality; the method of comparison and compatibility that allowed to define similarities in the content and operational components of teachers' CPD in the countries being studied; the structural and systematic method used for considering structural elements and functional peculiarities of the models, forms and methods, used in Great Britain, Canada and the USA.

The following empirical methods have been used: observations, questioning and interviewing teachers for gathering primary pedagogical information; interviewing and surveying research and teaching staff, administrative staff and students of educational departments, workers of teachers' associations and federations in Great Britain, Canada and the USA for clearing out specifics of organizing collaboration with schools; personal participation in workshops organized by Alberta Teachers' Association (Canada).

\section{RESULTS}

In terms of concept approach there has been made the analysis of the content of teachers' professional development and its realization at different levels of the system of continuing pedagogical education.

It has been cleared out that availability of normative and legislative documents concerning teachers' professional development and its functional purpose are common for the countries studied.

In Scotland the system of teachers' professional development is built in accordance with the standards of teaching profession: Standard for Initial Teacher Education, Standard for Full Registration, Standard for Chartered Teacher (The Scottish Government 2009), The Standard for Headship (Scottish Executive, 2005), that determine professional knowledge and awareness, professional skills, professional values and devotion (Мукан, 2011).

In England the system of professional development is characterized by its correspondence to the development of the teacher's career that embraces Qualified Teacher Status, Teachers on Induction and main scale, Teachers on the Upper Pay Scale (Post Threshold Teachers, Excellent Teachers), Advanced Skills Teachers, that reveal professional qualities, professional knowledge and awareness, professional skills.

In Wales the system of teachers' professional development is built according to Code of Professional Conduct and Practice for Registered Teachers, The Chartered Teacher Standards, National Standards for Headteachers, Statement of Professional Values and Practice, which define major principles of training and learning; building relations between a teacher and a student, parents, colleagues, other specialists with whom he/she cooperates to ensure high quality of educational process; professional development.

In the document of General Teaching Council for Northern Ireland "Teaching: the Reflective Profession" (General Teaching Council for Northern Ireland, 2007) there are defined 27 competences of a teacher being divided into 3 main groups that embrace professional values and practice; professional knowledge and awareness; professional skills and abilities. Every competence schematically reflects a certain stage in a teacher career cycle: teacher's initial training, induction, initial professional development, continuing professional development, collegial practice and improvement of school.

In Canada teachers' professional development is provided on the basis of some normative documents: Teaching Quality Standard Ministerial Order, Teacher Growth, Supervision and Evaluation (Alberta), Code of Professional Competence (Alberta, Saskatchewan); Standards for the Education, Competence \& Professional Conduct of Educators in British Columbia (Ministry of Education of British Columbia, 2008); The Standards of Practice for the Teaching Profession (Ontario), Code of Professional Practice 
(Manitoba); Code of Professional Conduct (New Brunswick); Code of Ethics (Newfoundland and Labrador, Prince Edward Island) and so on.

In such states as Alaska, California, Idaho, Illinois, Nebraska, Nevada, South Dakota, Texas, Wisconsin teachers' professional development is provided in accordance with the program document of The National Board for Professional Teaching Standards "What Teachers Should Know and Be Able to Do: The Five Core Propositions of the National Board" and standards for teaching subjects, that highlight the following: directives on which pedagogical activities are based; knowledge about students; knowledge about culture and multiculturalism; relations with homes, schools and communities; knowledge in the subject field; knowledge about the process of the subject matter acquisition; methods of teaching; assessment; a learning teacher; professional development. Other states use Standards for Staff Development, that are the basis for working out standards for teachers' development (e.g. Standards for Alaska's teachers, Rhode Island Quality Standards for Professional Development) and define context standards (learning communities, leadership, resources), process standards (students data analysis, evaluation, research, learning, cooperation) and content standards (equity, teaching quality, involvement of family and other stakeholders).

Model of unification of teachers' professional development (Mukan, Kravets, 2015) was used to analyze the content of teachers' professional development programs at several levels: individual level; school level; level of local education authorities; level of department/ ministry of education of state (the USA), province/territory (Canada), England, Scotland, Wales and Northern Ireland (Great Britain); level of external providers of professional development programs.

Using systemic approach there has been specified the component composition of the content of professional development in the countries studied. It turned out to embrace the following:

- professional knowledge (pedagogical knowledge, knowledge in the subject field, knowledge of the methods of teaching, knowledge of the methods of assessing students' learning activities, knowledge of learning environment management, knowledge concerning activities in the multicultural environment, knowledge necessary to support political, social fairness, knowledge concerning application of information and communication technologies in the educational process etc.);

-skills (self-development and self-education, providing educational services, developing syllabi and curricula, assessing effectiveness of teaching activities and students' learning achievements, cooperating with parents, members of the public, planning and school management activities as well as reforming the system of education as a whole);

- values and attitudes (foresee fundamental psychological and pedagogical, methodical, information and technological, practical, social and humanitarian training of teachers).

The analysis of teachers' professional development programs shows the availability of the attributes being inherent (common) for all the three countries, namely: efficiency (concerning time and costs); focus on everyday needs of teachers in their professional activities; highquality organization of presentations made by teachers and practical researchers; saturation with innovative and appropriate information; provision of the opportunity to practically apply the acquired theoretical knowledge; high probability of applying new knowledge and skills in learning environment; deepening the knowledge acquired during initial professional training, general concepts of the subject field; provision of continuity and regularity of learning, support and communication of teachers on the Internet; creation of the possibility to critically analyze professional development programs with the aim of improving them (Мукан, Магдач, 2010). 
In the systems of continuing pedagogical education in Great Britain, Canada and the USA various organizational models, methods and forms of teachers' professional development are used. Using the classification proposed by E. Villegas-Reimers (VillegasReimers, 2003), there has been studied the potential application of two groups of models, methods and forms of teachers' professional development: institutional models (professional development schools, university-school partnership, cooperation between different departments of institution, Schools' network, Teachers' network, distance education) and individual methods and forms of professional development (method of cooperative or collegial development, cascade or generation method, case study, skills development method, reflection, project method, narrative method, self-development, seminars, workshops, institutes, conferences, courses, observation of excellent practice, teachers' participation in new roles, portfolio, action research, students' performance assessment, supervision, coaching, mentoring).

Planning, organization and assessment of the efficiency of models, methods and forms of teachers' professional development in Great Britain, Canada and the USA are performed with the account of many factors, among them being the following: the role of school and educational leaders, the role of context (taking into account the divergence of characteristics of educational environment and professional community in which a teacher is working and learning); the state of development of the system of school education in the national and international educational environment; time factor; financial resources; the state of development of the system of continuing pedagogical education; sequence of teacher's professional development; use of innovative technologies for pedagogical purposes; the role of professional unions in teachers' professional development; the role of educators engaged in the system of continuing pedagogical education.

The above characterized models, forms and methods of professional development of American, British and Canadian teachers may serve as a basis for teachers' professional development in Ukraine and they need to be adapted to Ukrainian realities.

\section{CONCLUSIONS}

The content component of teachers' professional development in Great Britain, Canada and the USA is grounded on corresponding normative and legislative base (state standards of teaching profession - Great Britain, the USA; standards of professional development - the USA; codes of professional behavior and competence of teachers Canada), curricula and syllabi being developed in the conditions of continuing pedagogical education with the account of the demands of the international education environment to the competence of a contemporary teacher and country's state policies and are approved in the prescribed order.

Common features that characterize the content of professional development of American, British and Canadian teachers are:

- general pedagogical knowledge (learning environment, methods of teaching the discipline, classroom management, teaching process); knowledge of the discipline (content of the discipline and the branch of science, its structure); knowledge of the methods of teaching the discipline (conceptual foundations, methods of teaching, curricula, syllabi, teaching resources); knowledge about students (student's life environment); knowledge of the methods of assessing students' learning activities; knowledge of strategies, methods, and instruments of creating effective learning environment; knowledge of specifics of activities in the multicultural environment; knowledge necessary to maintain political, social fairness; knowledge of applying information and communication technologies in the teaching process; 
- skills concerning planning and control of self-development and self-education; providing educational services to the society; ensuring all-round development of students' personalities and cooperation with colleagues in the profession; skills of learning and teaching, defining learning interests, needs and problems of students; skills to develop syllabi and curricula, define their goals, analyze them and adapt to the realities of teaching practice on the basis of practical research; skills to assess the effectiveness of own activities and academic achievements of students; skills of cooperation with parents and members of the public; skills of organizing effective learning environment; skills of planning school activities and school management as well as reforming the system of education as a whole;

- professional values (moral and ethical, spiritual, social, civil, democratic).

The specifics of the content component of teachers' professional development lies in fundamental, methodical, psychological and pedagogical, social and humanitarian, information and technological, practical training of teachers that depend upon the stage of teachers' career cycle, the chosen profession, teachers' field of activity.

The operational component is characterized by a wide spectrum of organizational models, methods and forms of professional development, and their complex combination is done with the account of such factors as the state of development of the system of continuing pedagogical education and its role in the society, social and economic status of school and peculiarities of learning environment in which the teacher is working, corporate culture of school, the stage of teacher's career cycle, his/her interests and needs etc. It has been justified that the effectiveness of adoption (in particular, from country to country) and application of various forms and methods of teachers' professional development depends upon taking into account historical, social, economic and cultural aspects of education development.

Organizational models, forms and methods of teachers' professional development in Great Britain, Canada and the USA that are efficiently used in their complex combination have been characterized according to two major groups:

- institutional models (professional development schools, university-school partnership, cooperation between different departments of institution, Schools' network, Teachers' network, distance education);

- individual methods and forms of professional development (method of cooperative or collegial development, cascade or generation method, case study, skills development method, reflection, project method, narrative method, self-development, seminars, workshops, institutes, conferences, courses, observation of excellent practice, teachers' participation in new roles, portfolio, action research, students' performance assessment, supervision, coaching, mentoring).

Prospects for future research include the analysis of forms and methods of public school teachers' CPD through ICT in the countries under research.

\section{REFERENCES}

1. General Teaching Council for Northern Ireland. (2007). Teaching: the Reflective Profession. Incorporating the Northern Ireland Teacher Competencies. Belfast : General Teaching Council for Northern Ireland, $52 \mathrm{p}$.

2. Ministry of Education of British Columbia. (2012). Standards for Education, Competence and Professional Conduct of Educators in British Columbia. Vancouver: Ministry of Education of British Columbia, $4 \mathrm{p}$.

3. Mukan, N., Kravets, S. (2015). Methodology of Comparative Analysis of Public School Teachers' Professional Development in Great Britain, Canada, the USA. Comparative Professional Pedagogy, Volume 5, Issue 4, pp. 39-45. 
4. Scottish Executive. (2005). Ambitious, Excellent Schools. Standard for Headship. Edinburgh : Scottish Executive, $16 \mathrm{p}$.

5. The Scottish Government. (2009). Standard for Chartered Teacher. Edinburgh : The Scottish Government, 14 p.

6. Villegas-Reimers, E. (2003). Teacher Professional Development: an International Review of the Literature. UNESCO : International Institute for Educational Planning, 197 p.

7. Мукан, Н. В., Магдач, 3. Т. (2010). Зміст професійного розвитку вчителів загальноосвітніх шкіл Канади [The Content of Public School Teachers' Continuing Professional Development in Canada]. Вісник Львівського університету імені Івана Франка. Серія педагогічна [Bulletin of Lviv National University Named after Ivan Franko. Teching Science], No 26, pp. 186-192 (in Ukrainian).

8. Мукан, Н. В. (2011). Професійний розвиток учителів загальноосвітніх шкіл Великої Британії, Канади, США [The Public School Teachers' Professional Development in Great Britain, Canada, the USA]. Львів : Видавництво Львівської політехніки, 248 р. (in Ukrainian). 